\title{
Vil du ete lunsj med meg?
}

Eg veit kor fristande det er å dele brunostskiva med datamaskina og siste vekes epikriser.

Eller å skvulpe i seg kaffien medan ein signerer ut prøvesvar og fyller ut endelause skjema. Eller rett og slett å hoppe over lunsjen fordi antalet uferdige notat nærmar seg kritisk nivå.

Men eg spør likevel.

Eg treng nemleg nokon å snakke med. Nokon som også kjenner kor skoen trykkjer. Som kjenner på det ansvaret og den myndigheita til å ta avgjerder som ligg på legane. Nokon eg kan be om råd, på uformelt vis, men som like fullt kan vere rettleiande og viktig for å minske risikoen for å gjere feil eller overskride grenser. Nokon eg kan for- telje om mine mindre stolte augneblinkar som lege.

Eg treng også nokon å tulle og fjase med, som gjer det uthaldeleg $i$ alt det uuthaldelege me står i. Nokon som gjer at eg gler meg til å gå på jobb og treffe gode kollegaer. Som gjer at når eg ringer for ein konsultasjon eller ei tilvising, så kjenner eg faktisk ansiktet og personen eg snakkar med. Nokon eg kan bygge ein stolt legeidentitet saman med.

Eg trur dette vil gjere meg til ein betre lege.

Så dersom eg spør: «Vil du ete lunsj med meg?», håpar eg at du svarar ja.

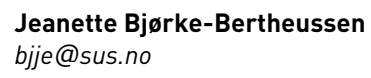

Jeanette Bjørke-Bertheussen (f. 1980) er lege i spesialisering ved Psykiatrisk divisjon, Stavanger universitetssjukehus.

Mottatt 10.3. 2013 og godkjent 21.3. 2013. Medisinsk redaktør Siri Lunde. 